\title{
Effect of hook size and seasonality on the artisanal long-line fishery of southern hake (Merluccius australis Hutton, 1872) in Chile
}

\author{
Efecto del tamaño de anzuelo y estacionalidad en la pesquería de espinel artesanal de la merluza \\ austral (Merluccius australis Hutton, 1872) en Chile \\ Dante Queirolo ${ }^{1}$ and Mauricio Ahumada ${ }^{1}$ \\ ${ }^{1}$ Laboratorio de Tecnología Pesquera, Escuela de Ciencias del Mar, Facultad de Recursos Naturales, Pontificia Universidad \\ Católica de Valparaíso, Casilla 1020, Valparaíso, Chile \\ dante.queirolo@ucv.cl
}

\begin{abstract}
Resumen.- Se estudió el efecto del tamaño de anzuelo y la estacionalidad en la pesquería artesanal con espinel de merluza del sur (Merluccius australis) en Chile. Se analizó el efecto de cuatro tamaños de anzuelos sobre las tallas y tasas de captura de merluza del sur (Merluccius australis) capturada con espinel mixto entre el Seno de Reloncaví y el Golfo de Ancud (41\%42'S a $42^{\circ} 48$ 'S). Se realizaron 60 lances de pesca en cuatro períodos (marzo, mayo, julio y septiembre), virándose un total de 59.294 anzuelos, capturándose 14.358 ejemplares equivalentes a $26.165 \mathrm{~kg}$. El análisis demostró la superposición de tallas de retención para cada tamaño de anzuelo en los meses de estudio, determinándose que no existen efectos significativos del anzuelo en la composición por tallas ni en las tasas de captura. Sin embargo, se observaron diferencias significativas en la tasa de captura entre períodos, fluctuando entre 31,75 y 16,17 individuos por 100 anzuelos entre marzo y septiembre, respectivamente. Lo anterior sugiere un análisis de alternativas de artes de pesca y de medidas de administración en la pesquería.
\end{abstract}

Palabras clave: Selectividad, aparejo, pesca artesanal, rendimientos de pesca, Océano Pacífico Suroriental

\section{Introduction}

Southern hake (Merluccius australis Hutton, 1872) is a widely distributed species in South America, found from $38^{\circ} \mathrm{S}$ to $55^{\circ} \mathrm{S}$ in the Atlantic Ocean (Cousseau \& Perrotta 2004) and between $35^{\circ} S$ and $57^{\circ} S$ in the Pacific Ocean (Rubilar et al. 2002). In Chile, it is an important target species for the artisanal and industrial sectors, with global annual catches of around 30,000 t.

Artisanal extractive activities are carried out in channels and fjords to the south of $41^{\circ} 30^{\prime}$ 'S, in an area commonly known as the 'inner waters'. Different longline designs are used to catch the resource according to the fishing ground and operation depth (Céspedes et al. 1998, Melo et al. 2004). Most catches come from Reloncaví Sound and Ancud Gulf, both of which are recognized as rearing sites due to the high proportion of

\begin{abstract}
The effect of hook size and seasonality on the artisanal long-line fishery of southern hake (Merluccius australis) in Chile was studied. We analyzed the effect of four hook sizes on the size-at-catch and catch rates of southern hake (Merluccius australis) caught with mixed long-lines between Seno de Reloncaví and Golfo de Ancud (4142'S-4248'S). Sixty fishing hauls were done in four periods (March, May, July, September); a total of 59,294 hooks were set and 14,358 specimens $(26,165 \mathrm{~kg})$ were caught. The analysis showed overlapping retention sizes for each hook size in the months studied, indicating no significant effects in either catch size composition or in catch rates between hooks of different size. Nevertheless, significant differences were observed between periods in the catch rates, fluctuating between 31.75 and 16.17 individuals per 100 hooks from March to September. The above results suggest that it is necessary to analyze alternative fishing gear and management measures for the fishery.
\end{abstract}

Key words: Selectivity, fishing gear, artisanal fishery, catch rates, Southeast Pacific Ocean

juvenile specimens in spring-summer (Rubilar et al. 2000). The local availability varies as does the relative participation of different age groups in the catches due to the trophic and reproductive migrations of the resource (Lillo et al. 2008).

In order to protect the juvenile fraction and preserve the stock of $M$. australis, the current regulation establishes a minimum legal size (MLS) of $60 \mathrm{~cm}$ total length. In terms of fishing gear, hooks $\mathrm{N}^{\circ} 6$ or upper, with a throat (height) less than $18 \mathrm{~mm}$ and a gap (width) less than 17 mm cannot be used (DS No. 245/1990 MINECON). This is based on the fact that several authors recognize longlines as size-selective catch systems (Johannessen 1983, Bjordal 1989, Løkkeborg et al. 1989, Løkkeborg \& Bjordal 1992, 1995, Huse \& Soldal 2000, Woll et al. 2001). Nonetheless, other reports indicate that the use of different hook sizes and bait for Merluccius merluccius 
(Linnaeus, 1758) resulted in overlapping size-at-retention curves, finding that the use of different-sized hooks only affects the catch rate (Erzini et al. 2000, 2001). Therefore, the present work compares the retention sizes and catch rates obtained with different hook sizes in the artisanal fishing of M. australis in its main catch zone.

\section{Material and methods}

Between March 5 and September 28, 2003, we performed experimental fishing trips on board three artisanal vessels operating in the area between Reloncaví Sound and Ancud Gulf ( $41^{\circ} 42^{\prime}-42^{\circ} 48^{\prime}$ 'S) (Fig. 1). Given the seasonal migration of the resource and the changes in its abundance, the north zone was occupied in March and May, whereas the southern zone was fished in July and September. A minimum of nine sets were performed each month, and the depth of the fishing grounds was variable between 150 and $300 \mathrm{~m}$.
The gear used corresponded to the traditional design used by the local fishermen. This consists of a mixed long-line with a horizontal polypropylene (PP) lift line that is $6 \mathrm{~mm}$ in diameter $1200 \mathrm{~m}$ long; 24 polyamide (PA) monofilament main lines (1.2 mm diameter; $100 \mathrm{~m}$ length) are attached to this horizontal lift line every $50 \mathrm{~m}$. Finally, 50 polyamide (PA) monofilament gangions $(0.9 \mathrm{~mm}$ diameter; $0.8 \mathrm{~m}$ long) with one hook at the end are attached to each of these main lines (Fig. 2). Traditionally, the fishermen used Mustad Kirby ' $\mathrm{J}$ ' type hooks $\mathrm{N}^{\circ}$ 8, thus we decided to use same type, increasing the size range ( $\mathrm{N}^{\circ}$ 5, 8, and 10) from March to September, adding $\mathrm{N}^{\circ} 3$ as of May to broaden the size range and thereby improve the resolution of the selective effect. The smallest hook $\left(\mathrm{N}^{\circ} 10\right)$ is $34.8 \mathrm{~mm}$ and the largest $\left(\mathrm{N}^{\circ} 3\right)$ is 70.9 mm (Table 1).

For each set, a minimum of 300 hooks of each number were used simultaneously, located alternately on the main line. The hooks were baited by hand with 'pejerrey'
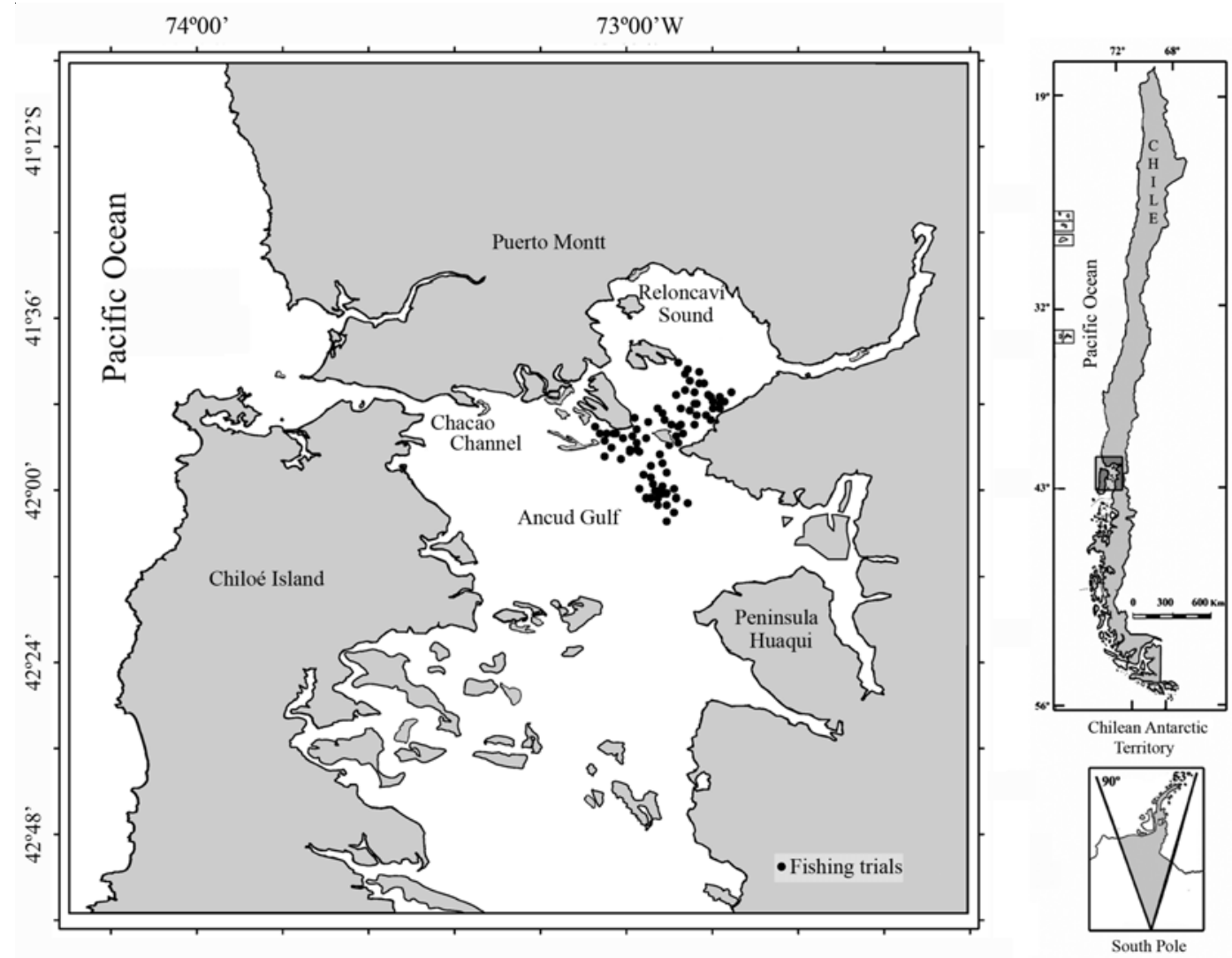

Figure 1

Map of the Reloncaví Sound and Ancud Gulf. Black dots indicate the location of the long-line fishing trials

Mapa del Seno de Reloncaví y Golfo de Ancud. En negro se indica la ubicación de los lances de pesca 


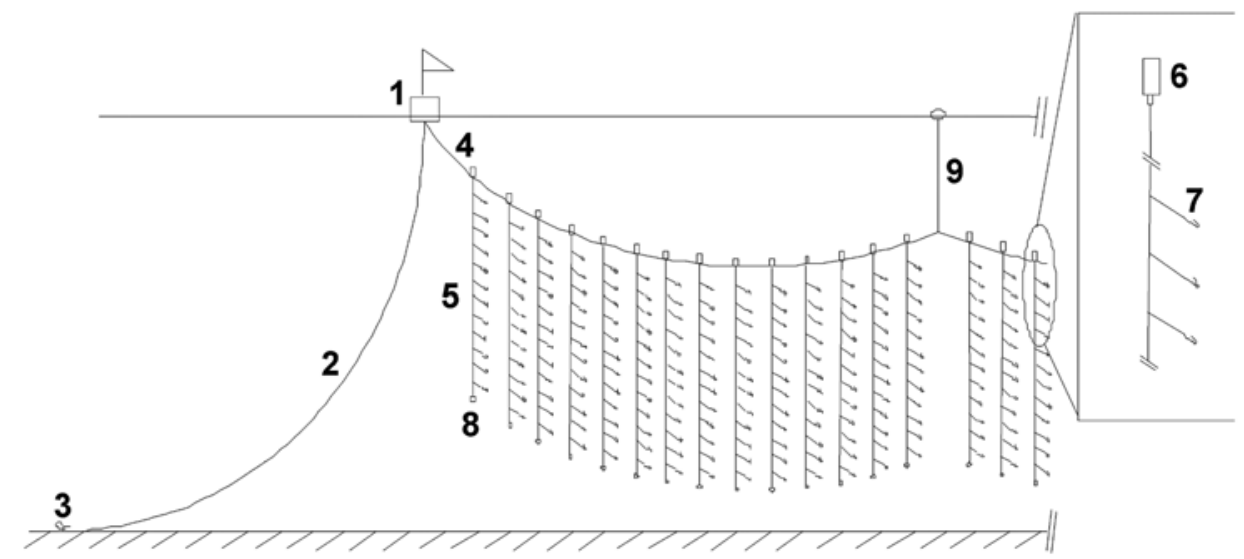

Figure 2

Diagram of the long-line used in the present study. 1: Buoy, 2: Buoy rope, 3: Anchor, 4: Lift line, 5: Main line, 6: Float (250-mL glass bottle), 7: Gangion and hook, 8: Weight (sinker), 9: Buoy line

Esquema del espinel empleado en el presente estudio. 1: Boya, 2: Orinque, 3: Ancla, 4: Retenida, 5: Línea madre, 6: Flotador (botellas de $250 \mathrm{~mL}$ ), 7: Reinal y anzuelo, 8: Peso, 9: Cabo de flotador

Table 1

\section{Main dimensions ( $\mathrm{mm}$ ) of hooks used in the experimental fishing of southern hake}

Dimensiones principales (mm) de los anzuelos utilizados en la pesca experimental de merluza austral

\begin{tabular}{rrrr}
\hline Hook N & Length & Gap & Throat \\
\hline 3 & 70.9 & 22.2 & 28.8 \\
5 & 56.6 & 18.0 & 22.6 \\
8 & 41.0 & 13.9 & 16.9 \\
10 & 34.8 & 10.8 & 13.7 \\
\hline
\end{tabular}

(Odonthesthes regia Humboldt, 1821) and sardine (Strangomera bentincki Norman, 1936) of like size and proportion according to availability, and the soak time (as commonly used by the fishermen) lasted from 4 to 12 $\mathrm{h}$ (diurnal and nocturnal sets indistinctly). We quantified the total catch and recorded the number of hooks set to determine the catch performance of each set.

We measured the total length (LT) of each specimen caught using an ichthyometer precise to $1 \mathrm{~cm}$, and recorded the sex of $25 \%$ of the specimens. The catch in weight was first estimated using the size-weight of a sample of 523 specimens; this was done on a digital balance precise to $10 \mathrm{~g}$. The parameters were obtained using the fit to a power function by ordinary minimum squares (OMS), after logarithmic linearization of the relationship:

$$
b_{0}^{*} L t_{l}^{b_{1}}
$$

The information was disaggregated according to set ' $\mathrm{i}$ ', in month ' $\mathrm{j}$ ' (March, May, July, September) and hook number ' $k$ ' $(3,5,8,10)$. The catch was quantified in number (individuals) and weight (g), and the catch rates in individuals per 100 hooks and g per hook. We compared the size structures by month, sex, and hook number. In order to verify the null hypothesis of equality of the respective size frequency distributions, we used a contrast hypothesis, specifically the non-parametric Kolmogorov-Smirnov test (Conover 1999). The null and alternative hypotheses were defined according to: $H_{0}$ : $F_{1}=F_{2}$ and $H_{a}: F_{1} \neq F_{2}$, respectively. For this, $F_{1}$ and $F_{2}$ corresponded to the respective pairs of the contrasted size frequency distributions.

To verify the existence of significant differences in the catch rates between months and hook sizes, we used a general linear model (GLM) that considered both the individual effect of the month and hook size as well as their interaction. We developed a multiple linear regression model, associating the factors to dichotomous variables. In all analyses, significance was established at value of $P<0.05$ by using software SPSS version 10.0 . 


\section{Results}

A total of 59,294 hooks were set in fishing trials (Table 2). The most intense fishing occurred in March in terms of hooks set (37.8\%), whereas July registered the fewest hooks set (13.7\%). Hook $\mathrm{N}^{\circ} 8$ was the most used in all fishing events (31.4\%), whereas $\mathrm{N}^{\circ} 3$ was the least used (16.6\%) since it was incorporated later in the program.

A total of 14,358 southern hake individuals were caught, of which 8,845 were males (61.6\%) and 5,513 females (38.4\%). Using size sampling for the total catch and the adjusted size-weight function (male: $\mathrm{b}_{0}=0.00521$, $\mathrm{b}_{1}=3.027, \mathrm{R}^{2}=0.93$; female: $\mathrm{b}_{0}=0.00429, \mathrm{~b}_{1}=3.076$, $\mathrm{R}^{2}=0.95$ ), it was possible to estimate a total catch of $26,165 \mathrm{~kg}$ in weight. Monthly, the catch varied between 13,128 kg in March and 3,007 kg in July (Table 2).

The catch presented the same size ranges for all the hook sizes, fluctuating between 34 and $100 \mathrm{~cm}$ (Fig. 3). The size frequency distributions of the monthly catches, by sex and hook number, were bimodal from March to July, with alternating primary and secondary modes corresponding to 60 and $73 \mathrm{~cm}$ total length, approximately. This tendency was reversed in September, particularly in females, with a unimodal distribution on $62 \mathrm{~cm}$ (Fig. 3). The total average longitude of the females was $65.9,67.0,66.0$, and $66.8 \mathrm{~cm}$ for hook numbers 3,5 , 8 , and 10; this was similar to the length of the males
$(65.8,67.1,66.7,66.3 \mathrm{~cm})$ caught on these same hooks (Table 3).

Graphically, the size frequency distributions obtained for sex and month with different hook sizes overlapped (Fig. 3). This can be seen in the acceptance of the null hypothesis for most of the hook combinations employed according to the Kolmogorov-Smirnov test. The main differences were observed in September, in particular for the pairs of hooks $3-5,3-8,5-10$, and 8-10 in females and 3-8, 5-8, 5-10, and 8-10 in males (Table 4).

The average monthly catch rates fluctuated between 13.0 to 33.5 individuals per 100 hooks (Table 5), with a maximum in March and a minimum in September, revealing a marked tendency of these catch rates to decrease during the study period (Fig. 4). Likewise, the catch rate in weight was greater in March (619.6 g per hook) and lower in September (234.3 g per hook) (Table 5). With the exception of May, hook $N^{\circ} 10$ had the highest catch rates, both in number and in weight.

We used the GLM to establish the existence of significant differences $(P<0.05)$ in the catch rates by month; no such effect was found for hook sizes or the interaction between month and hook (Table 6). Therefore, the linear regression model was constructed using only one factor (month), taking September as the pattern category. The catch rates recorded in March and May,

Table 2

Hooks recovered by month and catch (in number and weight) during the experimental fishing

Anzuelos virados por mes y captura (en número y peso) durante la pesca experimental

\begin{tabular}{|c|c|c|c|c|c|c|}
\hline Hook No. & Item & March & May & July & September & Total \\
\hline \multirow[t]{3}{*}{3} & Hooks & - & 2882 & 2026 & 4905 & 9813 \\
\hline & Catch in number & - & 755 & 320 & 646 & 1721 \\
\hline & Catch in $\mathrm{kg}$ & - & 1259.1 & 584.1 & 1167.1 & 3010.3 \\
\hline \multirow[t]{3}{*}{5} & Hooks & 7433 & 2839 & 1985 & 3352 & 15609 \\
\hline & Catch in number & 2274 & 795 & 395 & 439 & 3903 \\
\hline & Catch in $\mathrm{kg}$ & 4342.9 & 1362.7 & 797.8 & 799.9 & 7303.3 \\
\hline \multirow[t]{3}{*}{8} & Hooks & 7788 & 2808 & 2177 & 5855 & 18628 \\
\hline & Catch in number & 2422 & 787 & 446 & 902 & 4557 \\
\hline & Catch in $\mathrm{kg}$ & 4468.7 & 1316.1 & 859.5 & 1633.5 & 8277.8 \\
\hline \multirow[t]{3}{*}{10} & Hooks & 7195 & 2819 & 1913 & 3317 & 15244 \\
\hline & Catch in number & 2345 & 735 & 397 & 700 & 4177 \\
\hline & Catch in kg & 4316.8 & 1184.9 & 765.9 & 1305.8 & 7573.4 \\
\hline \multicolumn{2}{|c|}{ Total hooks } & 22416 & 11348 & 8101 & 17429 & 59294 \\
\hline \multicolumn{2}{|c|}{ Total catch in number } & 7041 & 3072 & 1558 & 2687 & 14358 \\
\hline \multicolumn{2}{|c|}{ Total catch in weight $(\mathrm{kg})$} & 13128.4 & 5122.8 & 3007.2 & 4906.3 & 26164.8 \\
\hline
\end{tabular}



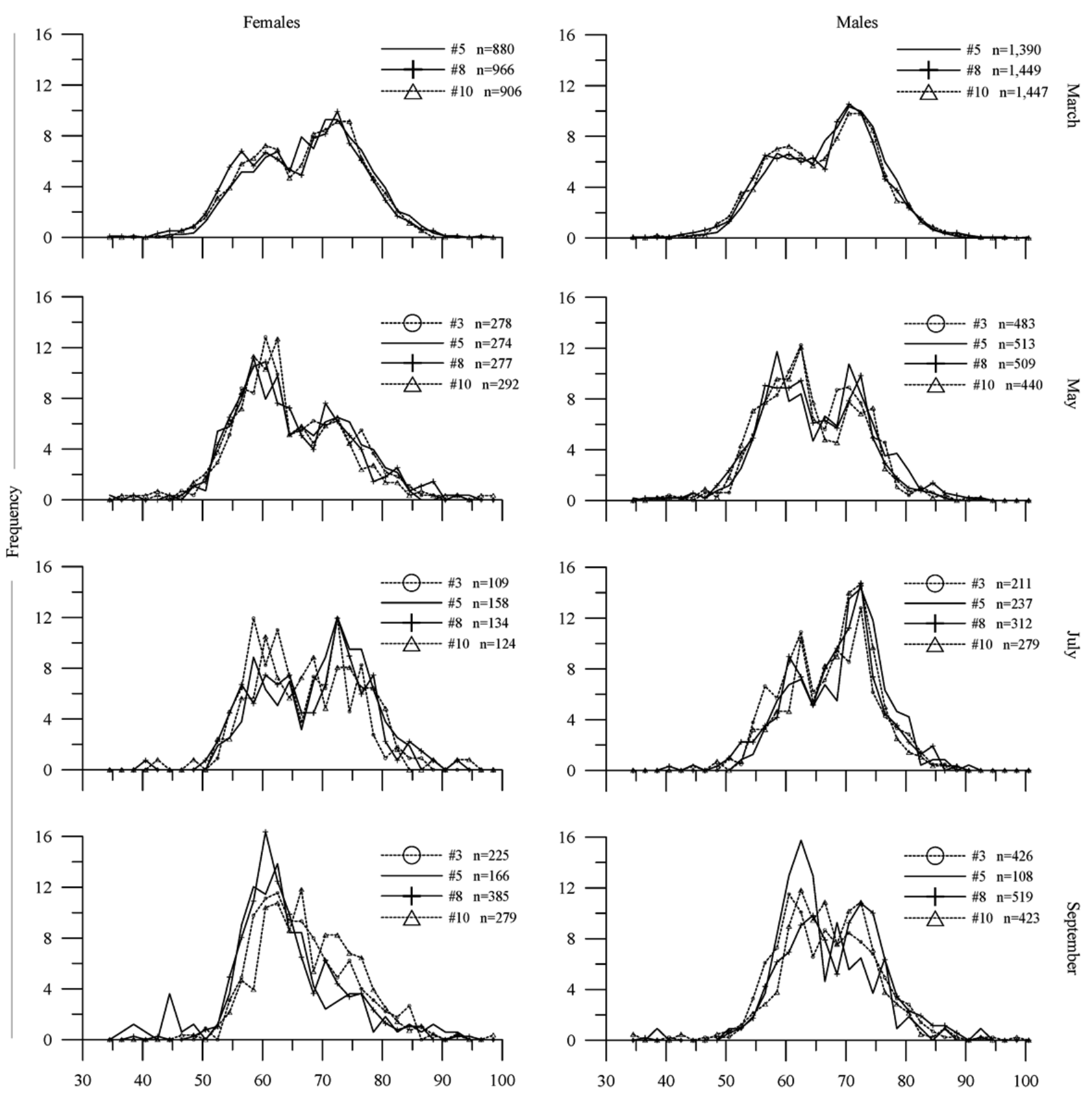

Length $(\mathrm{cm})$

Figure 3

Length frequency distributions of southern hake (M. australis) by sex, hook size and month

Distribuciones de frecuencias de tallas de merluza austral (M. australis) por sexo, tamaño de anzuelo y mes 
Table 3

Mean total length $(\mathrm{cm})$ in catches of southern hake by hook number, month, and sex. The values in parentheses show the coefficient of variation in percentage

Longitud total media $(\mathrm{cm})$ de capturas de merluza austral por número de anzuelo, mes y sexo. Entre paréntesis se indica el coeficiente de variación en porcentaje

\begin{tabular}{|c|c|c|c|c|c|c|}
\hline Sex & Hook No. & March & May & July & September & Total \\
\hline \multirow[t]{4}{*}{ Female } & 3 & - & $65.1(13.4)$ & $66.6(11.8)$ & $66.5(11.6)$ & $65.9(12.5)$ \\
\hline & 5 & $68.1(13.0)$ & $65.1(14.2)$ & $69.1(11.6)$ & $63.0(15.2)$ & $67.0(13.6)$ \\
\hline & 8 & $66.6(14.1)$ & $64.9(14.4)$ & $68.0(13.3)$ & $64.4(12.3)$ & $66.0(13.8)$ \\
\hline & 10 & $67.3(13.2)$ & $63.9(14.9)$ & $68.0(13.4)$ & 67.7 (11.6) & $66.8(13.4)$ \\
\hline \multirow[t]{5}{*}{ Male } & 3 & - & $64.6(12.2)$ & $67.1(11.2)$ & 66.7 (11.9) & $65.8(12.0)$ \\
\hline & 5 & $67.4(12.2)$ & $65.3(12.9)$ & $69.3(10.7)$ & $65.7(11.8)$ & $67.1(12.3)$ \\
\hline & 8 & $66.5(13.4)$ & $64.5(13.7)$ & $67.9(11.4)$ & $68.3(11.5)$ & $66.7(13.0)$ \\
\hline & 10 & $66.5(13.2)$ & $63.9(13.0)$ & $68.1(10.4)$ & $67.1(11.6)$ & $66.3(12.7)$ \\
\hline & & $67.7(8.8)$ & $64.7 \quad(8.7)$ & $68.1 \quad(7.8)$ & $66.6(8.1)$ & $66.5(8.6)$ \\
\hline
\end{tabular}

\section{Table 4}

Result of the Kolmogorov-Smirnov test used to compare the catch size frequency distributions for southern hake by sex. The $\mathbf{m}$ and $\mathbf{n}$ values are sampling size per hook and Dmax is the greatest difference in the cumulative distributions being compared

Resultado de la prueba Kolmogorov-Smirnov usada para comparar las distribuciones de frecuencias de tallas de merluza austral por sexo. Los valores de $\mathrm{m}$ y n son los tamaños de muestra por anzuelo y Dmax es la mayor diferencia entre las distribuciones acumuladas comparadas

\begin{tabular}{|c|c|c|c|c|c|c|c|}
\hline \multirow[t]{2}{*}{ Month } & \multirow[t]{2}{*}{ Hooks } & \multicolumn{3}{|c|}{ Female } & \multicolumn{3}{|c|}{ Male } \\
\hline & & $\mathrm{m} / \mathrm{n}$ & Dmax & $P$ value & $\mathrm{m} / \mathrm{n}$ & Dmax & $P$ value \\
\hline \multirow[t]{3}{*}{ March } & 5 vs. 8 & $873 / 958$ & 0.072 & $0.02 *$ & $1382 / 1441$ & 0.046 & 0.10 \\
\hline & 5 vs. 10 & $873 / 898$ & 0.043 & 0.37 & $1382 / 1438$ & 0.055 & $0.03^{*}$ \\
\hline & 8 vs. 10 & $958 / 898$ & 0.042 & 0.39 & $1441 / 1438$ & 0.016 & 0.99 \\
\hline \multirow[t]{6}{*}{ May } & 3 vs. 5 & $273 / 277$ & 0.042 & 0.97 & $482 / 512$ & 0.069 & 0.19 \\
\hline & 3 vs. 8 & $273 / 276$ & 0.043 & 0.96 & $482 / 508$ & 0.045 & 0.71 \\
\hline & 3 vs. 10 & $273 / 292$ & 0.061 & 0.69 & 482 / 439 & 0.059 & 0.39 \\
\hline & 5 vs. 8 & $277 / 276$ & 0.031 & 0.99 & $512 / 508$ & 0.509 & 0.51 \\
\hline & 5 vs. 10 & 277 / 292 & 0.068 & 0.53 & $512 / 439$ & 0.111 & $0.01^{*}$ \\
\hline & 8 vs. 10 & $276 / 292$ & 0.057 & 0.74 & $508 / 439$ & 0.059 & 0.39 \\
\hline \multirow[t]{6}{*}{ July } & 3 vs. 5 & $109 / 158$ & 0.159 & 0.08 & $211 / 237$ & 0.171 & $<0.001^{*}$ \\
\hline & 3 vs. 8 & $109 / 134$ & 0.103 & 0.54 & $211 / 312$ & 0.079 & 0.42 \\
\hline & 3 vs. 10 & $109 / 124$ & 0.097 & 0.65 & $211 / 279$ & 0.098 & 0.21 \\
\hline & 5 vs. 8 & $158 / 134$ & 0.081 & 0.74 & $237 / 312$ & 0.103 & 0.12 \\
\hline & 5 vs. 10 & $158 / 124$ & 0.117 & 0.31 & $237 / 279$ & 0.087 & 0.28 \\
\hline & 8 vs. 10 & $134 / 124$ & 0.061 & 0.97 & $312 / 279$ & 0.052 & 0.82 \\
\hline \multirow[t]{6}{*}{ September } & 3 vs. 5 & $225 / 166$ & 0.179 & $0.01^{*}$ & $426 / 108$ & 0.116 & 0.20 \\
\hline & 3 vs. 8 & $225 / 385$ & 0.143 & $0.01^{*}$ & $426 / 519$ & 0.103 & $0.01 *$ \\
\hline & $3 v s .10$ & $225 / 279$ & 0.086 & 0.32 & $426 / 423$ & 0.089 & 0.06 \\
\hline & 5 vs. 8 & $166 / 385$ & 0.074 & 0.54 & $108 / 519$ & 0.194 & $<0.001 *$ \\
\hline & 5 vs. 10 & $166 / 279$ & 0.256 & $<0.001^{*}$ & $108 / 423$ & 0.159 & $0.02 *$ \\
\hline & 8 vs. 10 & $385 / 279$ & 0.227 & $<0.001^{*}$ & $519 / 423$ & 0.089 & $0.05^{*}$ \\
\hline
\end{tabular}

* Significant differences $(P<0.05)$ 

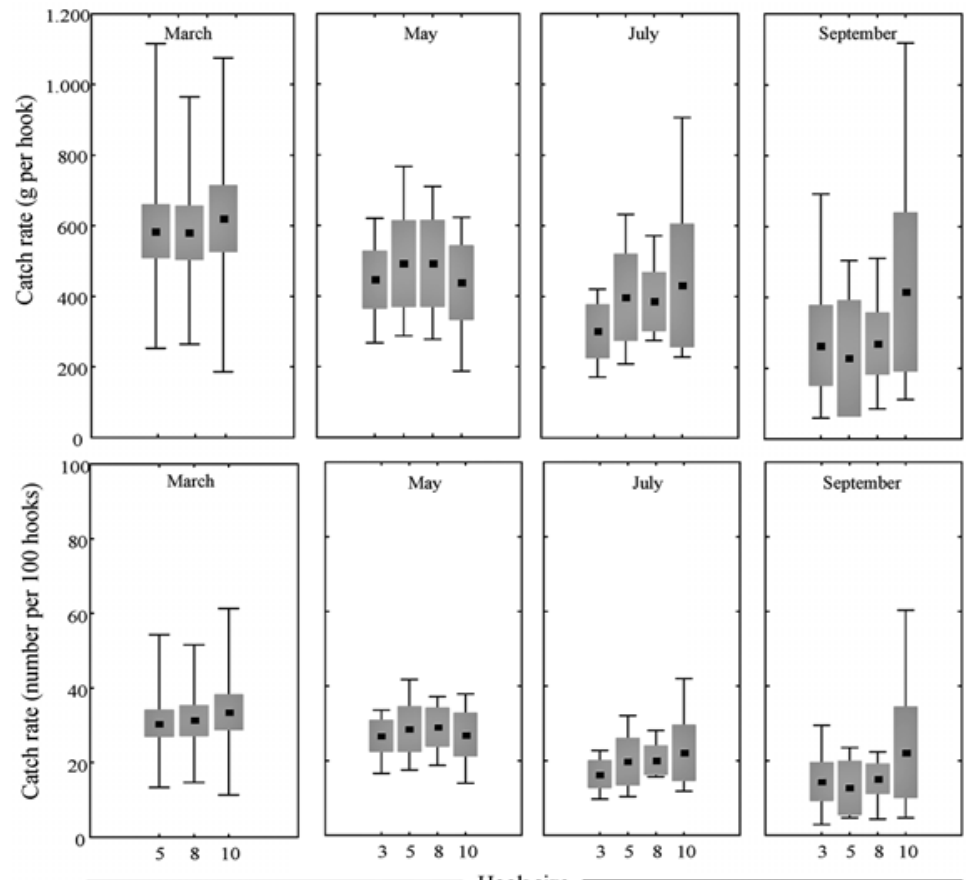

Figure 4

Catch rate of southern hake (M. australis) (in number and weight) by hook number and month. The plot shows the mean catch rate (black), $95 \%$ confidence interval (grey), and maximum and minimum catch rates (upper and lower bar)

Tasa de captura de merluza austral (M. australis) (en número y peso) según número de anzuelo y mes. Se indica la tasa de captura media (negro), intervalo de confianza al 95\% (gris), y la tasa de captura máxima y mínima (barra superior e inferior)

\section{Table 5}

Catch rate (number per 100 hooks and g per hook) of southern hake by hook size and month. The values in parentheses show the coefficient of variation in percentage

Tasa de captura (número por cada 100 anzuelos y g por anzuelo) de merluza austral por tamaño de anzuelo y mes. Los valores entre paréntesis indican el coeficiente de variación en porcentaje

\begin{tabular}{clcc}
\hline \multirow{2}{*}{ Hook N } & \multirow{2}{*}{ Month } & \multicolumn{3}{c}{ Catch rate } \\
\cline { 3 - 4 } & & $\mathrm{N}^{\circ}$ per 100 hook & g per hook \\
\hline \multirow{2}{*}{3} & March & - & - \\
& May & $26.7(20.0)$ & $446.2(23.3)$ \\
& July & $16.4(25.8)$ & $301.9(29.4)$ \\
& September & $14.4(56.8)$ & $270.3(70.0)$ \\
\multirow{5}{*}{5} & March & $30.5(29.0)$ & $584.2(32.1)$ \\
& May & $28.4(27.2)$ & $491.9(31.9)$ \\
& July & $19.7(37.6)$ & $398.4(36.4)$ \\
& September & $13.0(53.0)$ & $234.3(68.7)$ \\
8 & March & $31.3(32.0)$ & $579.4(32.6)$ \\
& May & $29.0(22.7)$ & $492.2(32.1)$ \\
& July & $20.1(22.3)$ & $385.9(25.3)$ \\
& September & $15.3(38.5)$ & $277.4(49.1)$ \\
& March & $33.5(35.0)$ & $619.6(37.8)$ \\
& May & $27.1(27.4)$ & $438.1(30.8)$ \\
& July & $22.1(40.1)$ & $431.5(48.0)$ \\
& September & $20.7(62.1)$ & $391.9(61.2)$ \\
\hline
\end{tabular}


Table 6

Summary of the general linear model (GLM) of the catch rate in number and weight

Resumen del modelo lineal general (MLG) de la tasa de captura en número y peso

\begin{tabular}{|c|c|c|c|c|c|c|}
\hline \multirow{2}{*}{ Variable } & \multicolumn{3}{|c|}{ Catch rate in number per 100 hooks } & \multicolumn{3}{|c|}{ Catch rate in g per hook } \\
\hline & $\mathrm{df}$ & $\mathrm{F}$ & $P$ value & df & $\mathrm{F}$ & $P$ value \\
\hline Hook & 3 & 2.00 & 0.12 & 3 & 1.46 & 0.23 \\
\hline Month & 3 & 35.87 & $<0.001 *$ & 3 & 27.37 & $<0.001 *$ \\
\hline Interaction & 8 & 0.46 & 0.88 & 8 & 0.63 & 0.76 \\
\hline
\end{tabular}

* Significant differences $(P<0.05), \mathrm{df}=$ degree freedom, $\mathrm{F}=\mathrm{F}$ ratio

Table 7

Summary of estimated regression coefficients and significant levels of the catch rate (in number and weight) for southern hake

Resumen de los coeficientes de regresión calculados y niveles de significancia de las tasas de captura (en número y peso) de merluza austral

\begin{tabular}{|c|c|c|c|c|}
\hline Variable & Parameter & Coefficient & Standard error $(\mathrm{b} i)$ & $P$ value \\
\hline \multirow[t]{4}{*}{$\mathrm{N}^{\circ}$ per 100 hooks } & b0 & 16.17 & 1.44 & $<0.001^{*}$ \\
\hline & b1 (March) & 15.58 & 1.75 & $<0.001 *$ \\
\hline & b2 (May) & 11.58 & 2.08 & $<0.001^{*}$ \\
\hline & b3 (July) & 3.40 & 2.15 & 0.11 \\
\hline \multirow[t]{4}{*}{ g per hook } & b0 & 295.31 & 29.19 & $<0.001 *$ \\
\hline & b1 (March) & 299.05 & 35.52 & $<0.001^{*}$ \\
\hline & b2 (May) & 171.77 & 42.13 & $<0.001 *$ \\
\hline & b3 (July) & 84.11 & 43.48 & 0.06 \\
\hline
\end{tabular}

* Significant differences $(P<0.05)$

both in number and in weight, were significantly different with respect to September $(P<0.05)$ (Table 7$)$. In particular, March showed a higher mean (15.58 individuals per 100 hooks and 299.05 g per hook) whereas, in May, the difference was less pronounced (11.58 individuals per 100 hooks and $171.77 \mathrm{~g}$ per hook), in both cases with respect to September (Table 7). The July catch rates, on the other hand, did not differ significantly from those of September.

\section{Discussion}

Long-lines are considered to be size-selective gear that allows safeguarding both the juvenile fraction as well as the mature specimens of the stock, preventing overfishing by growth and recruitment, respectively (Bjordal
1989, Løkkeborg \& Bjordal 1992, 1995, Huse \& Soldal 2000). This has been verified for many species, since smaller and larger specimens, relative to hook size, have a lower probability of being retained (Woll et al. 2001). Due to this, specific standards have been set for the Chilean M. australis fishery in terms of hook size. Nonetheless, the results obtained through the use of different hook sizes in the present study fail to show that this factor influences size selectivity. The size structures obtained using different hook sizes do not present consistent differences in the analyzed combinations (Table 4). In this sense, overlapping size structures for different hook sizes have been reported in a variety of investigations and for several species (Bertrand 1988, Erzini et al. 1996, 2000, 2003, Woll et al. 2001, Stergiou \& Erzini 2002). 
In the case of M. merluccius, Erzini et al. (2000) indicates that the lack of differences in the sizes of the catch is not surprising due to the predatory behaviour of the resource, as well as the morphological characteristics of its snout, the shape and dimension of which probably contribute to devouring relatively large-sized prey. Thus, obtaining differentiated size structures depends on the use of a wide range (at least 200\%) of hook sizes (Erzini et al. 1995, 1998). In this sense, the use of hooks between number $3(70.9 \mathrm{~mm})$ and $10(34.8 \mathrm{~mm})$ implies a maximum size difference of $103.7 \%$, which could be insufficient for detecting effects due to morphological characteristics and the predatory behaviour of $M$. australis.

On the other hand, no significant differences were detected in the catch rates due to the use of different hook sizes; this is consistent with the overlapping of size structures observed in each month of the study. Likewise, Erzini et al. (2000) registered a low difference in the $M$. merluccius catch rates, which fluctuated between 3.30\% and $1.61 \%$ in 1997 and $2.92 \%$ and $1.99 \%$ in 1998 , using hooks from $\mathrm{N}^{\circ} 5$ to $\mathrm{N}^{\circ} 10$. The catch rates tended to decrease as hook sizes increased.

The existence of a significant seasonal effect was verified on the catch rates, which dropped from 31.75 to 16.7 individuals per 100 hooks and from 594.36 to 295.31 g per hook from March to September. This is consistent with the dynamics of the resource and its seasonal migratory movements, as verified based on the catch size composition (Aguayo 1994, Rubilar et al. 2002) and the lower proportion of females in the fishing zone (Rubilar et al. 2000).

In this sense, Aguayo (1994) and Rubilar et al. (2002) indicate that the displacement of the resource is associated with reproductive phenomena in a north-south direction, from Reloncaví Sound to the exterior waters of the Pacific Ocean off Corcovado Gulf, an area to the south of Ancud Gulf. When considering $69.4 \mathrm{~cm}$ total length to be the size of first sexual maturity (Céspedes et al. 1996a, 1996b), this migratory movement would explain the increased proportion of specimens around a mode of 60 $\mathrm{cm}$ in the fishing area considered herein, a situation reported by Rubilar et al. (2002) for the same species and zone. Thus, as of July, the size structures present in Reloncaví Sound reflect a lower proportion of mature specimens due to the species' reproductive process.

In conclusion, increments in hook size within the range evaluated ( $\mathrm{N}^{\circ} 3$ to $\left.\mathrm{N}^{\circ} 10\right)$ did not produce a selective effect that helped to avoid the overfishing of M. australis by growth and recruitment. Additionally, catch rates did not vary due to hook size; however a significant seasonal effect was verified.

Thus, results imply the need to investigate other variables whose could influence size selectivity of hooks (bait, hook type), consider a wider range of hook size, or seek out alternative fishing gear for the fishery. Furthermore, one option for fishery management consists of assigning differential catch quotas considering the spatial-temporal distribution of the resource and its migratory processes.

\section{Acknowledgments}

The authors express their gratitude to Erick Gaete, Roberto Escobar and Alejandro Stack for their invaluable participation in fishing trips. We are grateful to Guido Plaza for his helpful comments and suggestions and to the anonymous reviewers for constructive criticisms of the manuscript draft. The present research was partially financed by the Fisheries Research Fund (FIP) under project FIP N 2002-08: 'Selectividad de aparejos de pesca utilizados por la flota artesanal en la pesquería de merluza del sur'.

\section{Literature cited}

Aguayo HM. 1994. Biology and fisheries of Chilean hakes (M. gayi and M. australis). In: Alheit J \& TJ Pitcher (eds). Hake fisheries, ecology and markets, pp. 305 -337. Chapman and Hall, London.

Bertrand J. 1988. Selectivity of hooks in the handline fishery of the Saya de Malha banks (Indian Ocean). Fisheries Research 6(3): 249-255.

Bjordal A. 1989. Recent development in long-line fishingcatching performance and conservation aspects. In: Campbell CM (ed). Proceedings of the world symposium on fishing gear and fishing vessels, pp. 21-24. Marine Institute, Memorial University of Newfoundland, Saint John's.

Céspedes R, C Toledo, L Adasme, P Rubilar, H Miranda \& C Techeira. 1998. Análisis del esfuerzo pesquero artesanal aplicado en merluza del sur en aguas interiores de la X, XI and XII Regiones. Informe Final Proyecto FIP-IT/97-13: 1-64 [on line] <http://www.fip.cl/prog_x_year/1997/ 9713.htm>

Céspedes R, C Techeira, J Blanco, V Ojeda, H Miranda, E Almonacid \& F Cerna. 1996b. Identificación de áreas de reclutamiento de merluza del sur en la XII Región. Informe Final Proyecto FIP-IT/94-24: 1-112. [on-line] <http:// www.fip.cl/prog_x_year/1994/9424.htm>

Céspedes R, L Adasme, H Reyes, M Braun, E Figueroa, V Valenzuela, V Ojeda \& R Roa. 1996a. Identificación de áreas de reclutamiento de merluza del sur en la zona sur 
austral. Informe Final Proyecto FIP-IT/93-20: 1-145. [online] <http://www.fip.cl/prog_x_year/1993/9320.htm>

Conover J. 1999. Practical non parametric statistics, 584 pp. Wiley, John \& Sons, New York.

Cousseau MB \& RG Perrotta. 2004. Peces marinos de Argentina: Biología, distribución, pesca, 167 pp. INIDEP, Mar del Plata.

Erzini K, JMS Gonçalves, L Bentes \& PG Lino. 1995. Small hook long-line selectivity study. Commission of the European Communitties, DG XIV, Final Report Ref. BIOECO/93/04: 1-90.

Erzini K, JMS Gonçalves, L Bentes, PG Lino \& J Cruz. 1996. Species and size selectivity in a multispecies Portuguese artisanal long-line fishery. ICES Journal of Marine Sciences 53: 811-819.

Erzini K, JMS Gonçalves, L Bentes, PG Lino \& J Ribeiro. 1998. Species and size selectivity in a 'red' sea bream longline métier in the Algarve (southern Portugal). Aquatic Living Resources 11: 1-11.

Erzini K, JMS Gonçalves, L Bentes, PG Lino \& J Ribeiro. 2001. The hake deepwater semi-pelagic («pedra-bola») long-line fishery in the Algarve (southern Portugal). Fisheries Research 51: 327-336.

Erzini K, JMS Gonçalves, L Bentes, PG Lino, J Ribeiro \& KI Stergiou. 2003. Quantifying the roles of competing static gears: Comparative selectivity of long-lines and monofilament gill nets in a multi-species fishery of the Algarve (southern Portugal). Scientia Marina 67(3): 341352.

Erzini K, L Bentes, M Castro, JMS Gonçalves, PG Lino, J Ribeiro, F Sousa \& E Puente. 2000. Hake semi-pelagic long-line selectivity and evaluation of selectivity models for hook and line gear. Commission of the European Communities, DG XIV/C/1, Final Report Ref. 96/062: 1190.

Huse I \& AV Soldal. 2000. An attempt to improve size selection in pelagic long-line fisheries for haddock. Fisheries Research 48: 43-54.

Johannessen T. 1983. Influence of hook and bait size on catch efficiency and length selection in longlining for cod (Gadus morhua L.) and haddock (Melanogrammus aeglefinus L.), M.Sc. Thesis, University of Bergen, Bergen, 109 pp.

Lillo S, E Molina, C Lang, V Ojeda, R Céspedes, L Adasme, R Meléndez, M Rojas \& A Saavedra. 2008. Evaluación hidroacústica de merluza del sur en aguas interiores de la X y XI Regiones, año 2006. Informe Final Proyecto FIPIT/2006-10: 1-105. [on-line] <http://www.fip.cl/proyectos/ 2006/2006-10.htm>

Løkkeborg S \& Å Bjordal. 1992. Species and size selectivity in long-line fishing: a review. Fisheries Research 13: 311322.

Løkkeborg S \& Å Bjordal. 1995. Size-selective effects of increasing bait size by using an inedible body on long-line hooks. Fisheries Research 24: 273-279.

Løkkeborg S, Å Bjordal \& A Fernö. 1989. Responses of cod (Gadus morhua) and haddock (Melanogrammus aeglefinus) to baited hooks in the natural environment. Canadian Journal of Fisheries and Aquatic Sciences 46: 1478-1483.

Melo T, P Pavez, C Hurtado \& D Queirolo. 2004. Selectividad de aparejos de pesca utilizados por la flota artesanal en la pesquería de merluza del sur. Informe Final FIP-IT/200208: 1-157. [on-line] <http://www.fip.cl/prog_x_year/2002/ 2002-08.htm>

Rubilar PS, R Céspedes, V Ojeda, L Adasme, A Cuevas, F Cerna \& G Ojeda. 2000. Análisis de la estructura y condición biológica de los recursos merluza del sur y congrio dorado en aguas interiores de la X, XI y XII Regiones. Informe Final FIP-IT/98-02: 1-83. [on-line] <http://www.fip.cl/prog_x_year/1998/9802.htm>

Rubilar PS, I Payá, A Zuleta, C Moreno, F Balbontín, H Reyes, R Céspedes, H Pool, LAdasme \& A Cuevas. 2002. Dinámica del reclutamiento de merluza del sur. Informe Final FIP-IT/2000-13: 1-142. [on-line] <http://www.fip.cl/ prog_x_year/2000/2000-13.htm>

Stergiou K \& K Erzini. 2002. Comparative fixed gear studies in the Cyclades (Aegean Sea): size selectivity of small-hook long-lines and monofilament gill nets. Fisheries Research 58: $25-40$.

Woll A, J Boje, R Holst \& A Gundersen. 2001. Catch rates and hook and bait selectivity in long-line fishery for Greenland halibut (Reinhardtius hippoglossoides, Walbaum) at East Greenland. Fisheries Research 51: 237246. 